\title{
Akut dekompanse kalp yetersizliği hastalarında oksidatif stres indeksinin değerlendirilmesi
}

\section{Evaluation of the oxidative stress index in patients with acute decompensate heart failure}

\author{
İdris Kırhan ${ }^{1} \mathbb{D}$, Hakan Büyükhatipoğlu ${ }^{2}$ (D) \\ 1 Harran Üniversitesi Tıp Fakültesi, İç Hastalıkları Ana Bilim Dalı, Şanlıurfa, Türkiye \\ 2 Harran Üniversitesi Tıp Fakültesi, l̇ç Hastalıkları Ana Bilim Dalı Onkoloji Bilim Dalı, Şanlıurfa
}

Öz.

Amaç: Dekompanse kalp yetersizliği (KY), dokuların metabolik intiyacının karşılanamaması sonucunda çeşitli metabolik ve fizyolojik süreçlere yol açar. Bu süreçte üretilen reaktif oksijen türleri zararlı oksidatif reaksiyonlara yol açar. Bu çalışmamızda, akut dekompanse KY hastalarında uygulanan tedavinin oksidatif stres parametreleri ile ilişkisini ve bu parametrelerde düzelmeyi sağlayıp sağlamadığını araştırmayı amaçladık.

Materyal ve Metot: Dekompanse KY nedeniyle yatan toplamda 40 hasta çalışmaya alındı. Hastaların yatışında tedavi öncesi ve taburculuk öncesinde tedavi sonrası antropometrik ölçümleri, ekokardiyografileri, rutin biyokimyasal parametreler yanında total antioksidan kapasite (TAK), total oksidatif seviye (TOS) ve bu ölçümlerin oranlarından elde edilen oksidatif stres indeksi (OSi) hesaplandı.

Bulgular: KY tedavisi sonrası nabız, sistolik kan basıncı ve diyastolik kan basıncında azalma, sol ventrikül ejeksiyon fraksiyonunda yükselme gözlendi (hepsi için $p<0.05$ ). Ek olarak KY tedavisi sonrası alınan TAK, TOS ve OSi değerlerinin tedavi öncesi değerlere göre anlamlı olarak daha fazla olduğu izlendi (hepsi için $p<0.05$ ). Yapılan korelasyon analizinde TAK ile sistolik ve diyastolik kan basıncı arasında negatif bir ilişki olduğu (sırasılyla r: -0,307, p:0.014; r: -0,393, p:0.001), EF ile de TAK ve OSi arasında negatif bir ilişki olduğu bulundu (sırasıyla r: $-0,298$, p:0.011; r:-0,326, p:0.005).

Sonuç: Oksidatif stresin dekompanse $\mathrm{KY}$ hastalarında yüksek olduğu ve tedavi ile kompansasyon sonrasında da bu yüksek seviyelerinin devam ettiği görüldü. Literatürde akut dekompanse KY tedavisinin bu parametreleri ne düzeyde etkilediğini gösteren çalışmalar sınırlı ve sonuçları tartışmalı olduğundan, bu konu ile ilgili daha fazla çalışma yapııması gerekmektedir.

Anahtar kelimeler: Total antioksidan kapasite, Total oksidatif seviye, Oksidatif stres indeksi, Kalp yetersizliğ

Abstract

Background: Decompansated heart failure (HF) causes various metabolic and physiological processes as a result of the failure to meet the metabolic needs of the tissues. Reactive oxygen species produced in this process cause harmful oxidative reactions. In this study, we aimed to investigate the relationship between the oxidative stres parameters and the treatment of acute decompensated patients with $\mathrm{HF}$.

Methods: A total of 40 patients with decompensated HF were included in the study. Anthropometric measurements, echocardiography, routine biochemical parameters, total antioxidant capacity (TAC), total oxidative level (TOL), and oxidative stres index (OSI) were obtained before admission and discharge.

Results: Pulse rate, systolic blood pressure and diastolic blood pressure decreased and left ventricular ejection fraction was increased after standard HF treatment ( $p<0.05$ for all $)$. Also post treatment TAC, TOL and OSI values were found to significantly higher than those pre-treatment values $(p<0.05$ for all). In corelation analysis there was a negative correlation between TAK and systolic and diastolic blood pressure ( $r:-0,307, p: 0.014 ;$ r: $-0,393, p: 0.001$, respectively), and a negative correlation was found between EF and CT and OSI (r: - 0.298, p: 0.011; r: -0.332, p: 0.005, respectively).

Conclusions: It was observed that oxidative stres was high in decompensated HF patients and these high levels were maintained in patients who were compensated after treatment. As there are limited studies on the effects of acute decompensated HF treatment on these parameters in the literature, further studies are needed on this subject, since the results are limited and the controversial.

Key words: Total antioxidant capacity, Total oxidative level, Oxidative stress index, Heart failure

Sorumlu Yazar $I$

Corresponding Author

Dr. İdris Kırhan

Harran Üniversitesi, Tıp Fakültesi,

İç Hastalıkları Ana Bilim Dalı,

Osmanbey Kampüsü,

63300, Haliliye, Şanlıurfa

Tel: +90 5322095463

E-mail: idriskirhan@gmail.com

Geliş tarihi / Received: 31/01/2019

Kabul tarihi / Accepted: 01/08/2019

DOI: 10.35440/hutfd.520377

${ }^{*}$ Bu makale Dr. İris Kırhan'ın

Tıpta Uzmanlık tezinden üretilmiştir 


\section{Giriş}

Kalp yetersizliği (KY), kardiyak anormalliklerin yol açtığı ve fizyolojisinde nörohormonal, renal ve hemodinamik cevapların rol oynadığı klinik bir sendromdur. KY, farklı kardiyak hastalıkların seyrinde son evrede ortaya çıkmakta olup önemli bir mortalite ve morbidite nedenidir (1). Ortalama insan ömrünün uzaması ve $K Y$ tedavisindeki önemli ve etkili tedaviler sonucunda $\mathrm{KY}$ insidansı artış göstermektedir $(2,3)$. Sürekli takip ve ilaç kullanımı gerektirmesi, sık hastanede yatış gerektirmesiyle ülke ekonomilerinde de önemli bir mali yük artışına neden olmaktadır (2). Dekompanse kalp yetersizliği (DKKY), önceden KY olduğu bilinen ve çoğu zaman tedavi almakta olan hastalarda KY semptomlarının ağılaşması, sistemik ve pulmoner konjesyon bulgularının ortaya çıkmasıyla karakterizedir. Kronik KY hastalarının \%15-20' si akut dekompansasyon nedeniyle hospitalize edilmektedir. Tedavideki tüm gelişmelere rağmen 5 yıllık mortalite oranları $\% 60$ ' lara ulaşmakta olup bu oran çoğu malignitenin mortalitesinden bile daha yüksektir. Dekompanse kalp yetersizliğinde kardiyak atım hacminin dokuların metabolik intiyacını karşılayamayacak seviyede azalması organizmada çeşitli metabolik ve fizyolojik süreçlere neden olur. Bu metabolik ve fizyolojik süreçte üretilen reaktif oksijen türleri zararlı oksidatif reaksiyonlara neden olur. Oksidan-antioksidan denge oksidatif yöne kayarsa oksidatif stres oluşur. Daha önceki çalışmalarda KY gelişen hastalarda süperoksit dismutaz (SOD), katalaz (CAT), glutatyon peroksidaz (GSH-Px) ve E vitamini gibi miyokardiyal antioksidanlar azalırken, serbest oksijen radikallerinin ve oksidatif stresin arttığı gösterilmiştir (4-10).

Bizde bu çalışmamızda, oksidatif stresin değerlendirildiği çalışmalardan farklı olarak, akut DKKY hastalarında uygulanan tedavinin oksidatif stres parametreleri ile ilişkisini ve bu parametrelerde düzelmeyi sağlayıp sağlamadığını araştırmayı amaçladık.

\section{Materyal ve Metod Çalışma dizaynı ve hastalar}

Bu prospektif, gözlemsel kesitsel çalışmaya, Ağustos-2010 ile Ocak-2011 tarihleri arasında hastanemiz dahiliye ve kardiyoloji kliniklerinde takip edilen dekompanse sistolik KY olan 40 hasta dahil edildi. Çalışma için hastanemizden lokal etik kurul onayı alındı. Tüm hastalardan yazılı ve sözlü onay alındı.

DKKY, hızlı başlayan ya da bulgu ve semptomları hızlı bozulma gösteren, kardiyak muayene, akciğer grafisi bulguları ile tespit edilen kardiyak fonksiyonlarda yetersizlik olarak tanımlandı. Daha önceden koroner arter hastalığı öyküsü olan ve bu nedenle perkütan girişim ile veya cerrahi revaskülarizasyon ile tedavi edilmiş iskemik kardiyomiyopatili hastalardan $\mathrm{KY}$ tablosu ile acil servise veya kardiyoloji polikliniğine başvuran hastalar çalışmaya alındı. Bütün hastaların standart KY tedavisi öncesi ve tedavi sonrası (dekompanse oldukları dönem ve tedavi sonrası kompanse olduktan sonra) ayrıntilı muayeneleri yapılıp, antropometrik ölçümleri alındı. Hastaların ekokardiyografi tetkikleri üniversitemiz kardiyoloji kliniğinde, hastalar hakkında önceden bilgisi olmayan tek bir kardiyoloji öğretim üyesi tarafınca yapıldı. Ekokardiyografileri yapılırken tüm hastaların görüntüleri en az 3 siklüs olacak şekilde kaydedilip aynı hekim tarafınca 2 kez ölçüm alınarak analizlere eklendi. Ekokardiyografi tetkikleri sonrasında hastalardan kan tetkikleri alındı.

Çalışmanın bazal değişkenleri olarak yaş, cinsiyet, nabız, sistolik (SKB) ve diyastolik (DKB) kan basıncı, HT öyküsü belirlendi. Tüm hastaların yatış boyu ve kiloları hesaplandı. $\mathrm{HT}$, SKB için $140 \mathrm{mmHg}$ ve üstü, DKB için $90 \mathrm{mmHg}$ ve üzeri veya antihipertansif ilaçların kullanımı olarak tanımlandı. Na (sodyum), K (potasyum), üre, kreatinin, açlık kan şekeri, trigliserit (TG), total kolesterol (TK), HDL-Kolesterol (HDL-K), LDL-Kolesterol (LDL-K) serum değerleri ticari ölçüm kiti (Abbott $\left.{ }^{\circledR}\right)$ ile otoanalizörde çalışıldı (Aeroset ${ }^{\circledR}$, Germany).

Aşağıda belirtilen özelliklerden en az birini bulunduran hastalar çalışmaya dahil edilmediler: Son 1 ay içerisinde geçirilmiş akut koroner sendrom; noninvaziv testlerle ya da ventrikülografi ile kanıtlanmış ciddi iskemisi olan hastalar; sinüs ritmi dışında ritimler; akut miyokardit ya da perikardit; doğumsal kardiyovasküler anomaliler; kronik obstrüktif akciğer hastalığı veya kor pulmonale; kronik karaciğer hastalıklarl; kronik böbrek hastalıklarl; anemik hastalar ( $\mathrm{Hb}$ erkeklerde $<13 \mathrm{gr} / \mathrm{dl}$, kadınlarda $<12 \mathrm{~g} / \mathrm{dl}$ ); son 1 ayda geçirilmiş cerrahi operasyonlar; neoplastik hastalıklar; bilinen tiroid disfonksiyonu; karvedilol, nebivolol gibi antioksidan beta-bloker kullananlar; kaptopril, zofenopril gibi antioksidan özelliklere sahip ACE inhibitörü kullananlar; statin ve antioksidan vitamin kullananlar; alkol kullananlar.

\section{Kan örneklerinin değerlendirilmesi}

Çalışmaya alınan her bir hastanın ön kol venöz damarından alınan 5 cc kan örnekleri biyokimya tüplerine konuldu. Daha sonra total oksidan seviye (TOS) ve total antioksidan kapasite (TAK) düzeylerinin ölçüleceği serum örneği elde etmek için tüpler 10 dakika kadar 1500 r/dak devir hızında santrifüj edildi. Elde edilen tüm serum örnekleri etiketlendikten sonra analiz edilecekleri güne kadar biyokimya laboratuvarında derin dondurucuda $-80^{\circ} \mathrm{C}$ 'de saklandı.

Total Antioksidan Kapasite (TAK): Erel tarafından geliştirilen tam otomatik bir yöntem olup, güçlü serbest radikallere karşı vücudun total antioksidan kapasitesini ölçen bir metottur (11).

Prensip: $\mathrm{Fe}^{2+}$-0-dianisidine kompleksi hidrojen peroksid ile Fenton tipi reaksiyon oluşturarak serbest oksijen $(\mathrm{OH})$ radikalini oluşturur. Bu güçlü reaktif oksijen türü indirgen düşük pH'da renksiz o-dianisidine molekülü ile reaksiyona girerek sarı-kahverengi dianisidyl radikallerini oluştururlar. 
Dianisidyl radikalleri ileri oksidasyon reaksiyonlarına katılarak renk oluşumu artmaktadır. Ancak örneklerdeki antioksidanlar bu oksidasyon reaksiyonların bastırarak renk oluşumunu durdurmaktadırlar. Bu reaksiyon otomatik analizörde spektrofotometrik olarak ölçülerek sonuç verilmektedir.

Total Oksidan Seviye (TOS): Erel tarafından geliştirilen tam otomatik kolorimetrik bir yöntemdir.

Prensip: Örnekte bulunan oksidanlar ferröz iyon-odianisidine kompleksini ferrik iyona oksitlerler. Ortamda bulunan gliserol bu reaksiyonu hızlandırarak yaklaşık üç katına çıkarmaktadır. Ferrik iyonlar asidik ortamda xylenol orange ile renkli bir kompleks oluştururlar. Örnekte bulunan oksidanların miktarıyla ilişkili olan rengin şiddeti spektrofotometrik olarak ölçülmektedir.

Oksidatif Stres İndeksi (OSI): Total Oksidan Seviye (TOS)/Total Antioksidan Kapasite (TAK)'ye bölünerek Oksidatif Stres Indeksi (OSi) hesaplandı.

Ekokardiyografik inceleme

Ekokardiyografik inceleme, hastalar sol lateral dekübit pozisyonuna yatırılarak Aloka marka (Aloka SSD 5000 ultrasound, Aloka Inc., Tokyo, Japan) ekokardiyografi cihazı $2.5 \mathrm{MHz}$ transdüser kullanılarak, parasternal uzun ve kısa aks ve apikal 2, 4, 5 boşluk görüntülerden yapıldı. Ekokardiyografik ölçümler Amerikan Ekokardiyografi Derneği'nin önerdiği ölçüt temel alınarak yapıldı (12). Hastalara sırasıyla M-mod ekokardiyografik, iki boyutlu ekokardiyografik, pulsed ve continuous wave Doppler ve renkli Doppler ekokardiyografik değerlendirilmeler yapıldı. Parasternal uzun akstan, M-mod (mitral kordal seviyede, ventrikülün uzun aksına dik) ile sol ventrikül diyastol sonu çapı (LVDD), sol ventrikül sistol sonu çapı (LVSD), interventriküler septum kalınlığı, arka duvar kalınlığı kaydedildi. Sol ventrikül ejeksiyon fraksiyonu (EF) modifiye Simpson metodu ile hesaplandı (13).

\section{Istatistiksel analiz}

Bütün istatistiksel analizler için SPSS 11.5 (SPSS Inc., Chicago, Illinois, USA) kullanıldı. Devamlı değişkenlerin dağıIımı değerlendirmek için Kolmogorov-Smirnov testi kullanıldı. Normal dağılım gösteren veriler ortalama \pm standart deviasyon olarak verildi. Hastaların serum TAK, TOS ve OSi değerleri ile diğer değişkenlerin tedavi öncesi ve sonrası karşılaştırmaları Paired-T testi ile analizi edildi. Bu faktörlerin ilişkili olduğu parametrelerin araştırımasında ise Pearson korelasyon analizi uygulandı. $P<0.05$ 'in altındaki değerler istatistiksel olarak anlamlı kabul edildi.

\section{Bulgular}

Hastalara ait genel klinik, antropometrik ve biyokimyasal bulgular Tablo 1' de özetlenmektedir. Hastaların 22'si bayan, 18 'i erkek; ortalama yaşları: $51 \pm 11$ yı idi.

Tedavi öncesi ile tedavi sonrası değerler analiz edildiğinde nabız, sistolik kan basıncı, diyastolik kan basıncı değerle- rinde tedavi sonrası azalma olduğu, EF değerinde ise yükselme olduğu izlendi (hepsi için $p<0.05$ ). TAK, TOS, OSi değerleri ise tedavi sonrasında, tedavi öncesine göre daha yüksek değerlerde ölçüldü (hepsi için $p<0.05)$ (Şekil 1). Diğer biyokimyasal veriler ve lipit profili değerleri açısından tedavi öncesi ve tedavi sonrası arasında anlamlı fark yoktu ( $p>0.05$ ) (Tablo 2).

Pearson korelasyon analizinde TAK ile sistolik ve diyastolik kan basıncı arasında negatif bir ilişki olduğu (sırasıyla r: 0,307, p:0.014; r: -0,393, p:0.001), EF ile de TAK ve OSi arasında negatif bir ilişki olduğu bulundu (sırasıyla r: 0,298, p:0.011; r:-0,326, p:0.005). Diğer bakılan paramatreler ile TAK, TOS ve OSI değerleri arasında herhangi bir anlamlı korelasyon saptanmadı (hepsi için $p>0.05$ ).

Tablo 1. Çalışmaya alınan olguların genel demografik ve laboratuvar bulguları

\begin{tabular}{lc}
\hline Değişkenler & $\begin{array}{c}\text { Hasta populasyonu } \\
\text { (sayl=40) } \\
\text { Sayı (\%)/ Ortalama } \pm S S\end{array}$ \\
\hline Cinsiyet (Erkek/Total, \%) & $18 / 40(\% 45)$ \\
Yaş (yıl) & $51.3 \pm 11.1$ \\
Boy (cm) & $160.8 \pm 8.2$ \\
Kilo (kg) & $73.2 \pm 15.1$ \\
Nabız (atım/dakika) & $98.4 \pm 12.7$ \\
Hipertansiyon (olan/toplam, \%) & $12 / 40(\% 30)$ \\
Diabetes Mellitus (olan/toplam, & $19 / 40(\% 47)$ \\
\%) & $14 / 40(\% 35)$ \\
Dislipidemi (olan/toplam, \%) & $9 / 40(\% 22)$ \\
Sigara (kullanan/toplam, \%) & $205.7 \pm 57.9$ \\
Total kolesterol (mg/dL) & $106.1 \pm 28.4$ \\
LDL-Kolesterol (mg/dL) & $42.2 \pm 14.9$ \\
HDL-Kolesterol (mg/dL) & $157.6 \pm 92.5$ \\
Trigliserit (mg/dL)
\end{tabular}

LDL: düşük dansiteli lipoprotein; HDL: yüksek dansiteli lipoprotein; SD: standart sapma

Veriler sayı (yüzde) veya ortalama sstandart sapma olarak sunulmuştur.

\section{Tartışma}

Bu çalışma, DKKY hastalarında kompansasyonun sağlanması ile vital bulgularda iyileşme, sol ventrikül ejeksiyon fraksiyonunda düzelme olduğu görülmüştür. Kalp yetersizliği kompansasyonu sağlanması için verilen tedavinin ise oksidatif stresi arttırdığını göstermiştir.

Oksidatif stres, reaktif oksijen radikallerinin, vücudun doğuştan-başlangıçtan olan anti-oksidan enzim sisteminin baskıladığı bir durum olarak tanımlanmaktadır. Serbest oksijen radikalleri (SOR), kimyasal olarak aktif olan ve oksijen metabolizmasının bir yan ürünü olarak oluşan oksijen içeren moleküllerdir. SOR üretimi antioksidan savunma kapasitesini aştığında, oksidatif stres biyolojik dokunun işlevsel ve yapısal bütünlüğü üzerinde zararlı bir etkiye sahiptir. Bu serbest radikallerin dokulara zarar veren etkilerini sınırlandırmak için hücreler kendilerini süperoksit dismutaz (SOD), katalaz ve glutatyon peroksidaz gibi enzimlerle savunurlar. SOR ve doğal olarak artan oksidatif stres, direkt olarak membran lipidleri, proteinler ve nükleik asitlerle reaksiyona 
girerek apoptoz ve nekroz yoluyla hücresel fonksiyon bozukluğu ve ölüme neden olur. Ayrıca pro-enflamatuar sitokin üretimini tetiklemek için sinyal molekülleri olarak da işlev görebilir. Kalp hücrelerinde potansiyel kontraktil disfonksiyon ve yapısal değişiklikleri sağlayan SOR kaynakları şunlardır: ksantin oksidaz, NADPH oksidazlar, lipoksijenazlar, siklo-oksijenazlar, sitokrom P-450, nitrik oksit sentaz, peroksidaz, mitokondriyal solunum zinciri ve diğer hemoproteinler.

Tablo 2. Çalışmaya alınan olguların tedavi öncesi ve tedavi sonrası klinik, ekokardiyografik ve biyokimyasal bulguları

\begin{tabular}{|l|l|l|l|}
\hline Değişkenler & $\begin{array}{l}\text { Tedavi öncesi } \\
\text { (sayı=40) }\end{array}$ & $\begin{array}{l}\text { Tedavi sonrası } \\
\text { (sayı=40) }\end{array}$ & p değeri \\
\hline Nabız (atım/dakika) & $98.4 \pm 12.7$ & $75.3 \pm 14.1$ & 0.01 \\
\hline $\begin{array}{l}\text { Sistolik kan basıncı } \\
\text { (mmHg) }\end{array}$ & $142.9 \pm 18.7$ & $112.4 \pm 24.5$ & 0.001 \\
\hline $\begin{array}{l}\text { Diyastolik kan ba- } \\
\text { sıncı (mmHg) }\end{array}$ & $88.6 \pm 12.9$ & $75.2 \pm 12.5$ & 0.001 \\
\hline $\begin{array}{l}\text { Ejeksiyon Fraksi- } \\
\text { yonu (\%) }\end{array}$ & $32.8 \pm 5.2$ & $38.6 \pm 4.5$ & 0.001 \\
\hline Sodyum (mg/dL) & $131.3 \pm 22.0$ & $138.5 \pm 14.8$ & $>0.05$ \\
\hline Potasyum(mg/dL) & $4.2 \pm 0.5$ & $3.9 \pm 1.7$ & $>0.05$ \\
\hline $\begin{array}{l}\text { Açlık kan şekeri } \\
\text { (mg/dL) }\end{array}$ & $128.3 \pm 71.5$ & $108.6 \pm 19.8$ & $>0.05$ \\
\hline Üre (mg/dL) & $34.4 \pm 11.2$ & $32.9 \pm 15.2$ & $>0.05$ \\
\hline Kreatinin (mg/dL) & $0.63 \pm 0.5$ & $0.72 \pm 0.3$ & $>0.05$ \\
\hline TAK & $0.94 \pm 0.19$ & $1.04 \pm 0.17$ & 0.009 \\
\hline TOS & $16.16 \pm 5.30$ & $26.06 \pm 7.07$ & 0.001 \\
\hline OSi & $1.82 \pm 0.75$ & $2.64 \pm 0.91$ & 0.001 \\
\hline
\end{tabular}

TAK: total antioksidan kapasite; TOS: total oksidan seviye; OSi: oksidatif stress indeksi

Veriler ortalama土standart sapma olarak sunulmuştur.

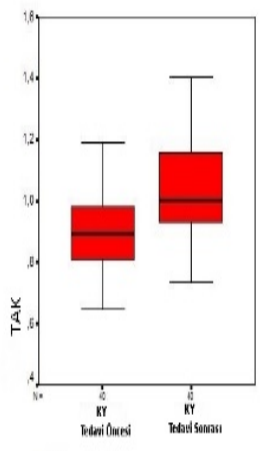

GRUP

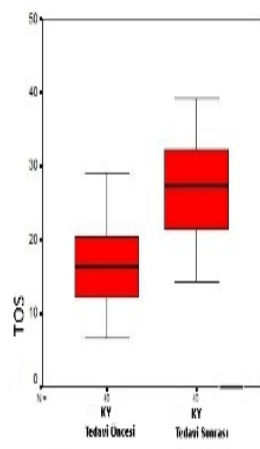

GRUP



GRUP
Şekil 1. Tedavi öncesi ve sonrası TAK, TOS ve OSI değerleri TAK: total antioksidan kapasite; TOS: total oksidan seviye; OSI: oksidatif stress indeksi; KY: kalp yetersizliği

Hayvan modellerinde ve insanlarda yapılan çalışmalarda KY'nin tüm aşamalarında oksidatif stresin varlığına ilişkin çok büyük kanıtlar vardır (14-16). Hayvan modellerinde, hem oksidatif stresin artması hem de antioksidanların azalmış olması, KY' nin gelişimi ve yayılmasıyla açıkça ilişkilendirilmiştir. Hayvan modellerinde SOD, katalaz ve glutatyon aktivitesinde azalma KY gelişimi ile ilişkilidir $(17,18)$. Miyokard infarktüsünün oluşturulduğu hayvan modellerinde glutatyon peroksidazın aşırı ekspresyonu, sol ventrikül dilatasyonunun ve fonksiyon bozukluğunun düzelmesinde ve sağ kalımın iyileşmesinde faydası olmuştur (19).
KY' li hastalarda genellikle oksidan türlerin ve metabolitlerinin seviyeleri $\mathrm{KY}^{\prime}$ nin farklı evrelerinde de yükseldiği görülmüştür (20).

Yapılan bir çalışmada SOR' nin tamamen zararlı olmayabileceği, hatta dokuların küçük SOR konsantrasyonlarına maruz kalmasının endojen anti-oksidanların gen ekspresyonunu uyardığı ve bu nedenle koruyucu olabileceği öne sürülmüştür (21). Başka bir çalışmada da kısa süreli bir oksidatif stres durumunda, kalbin kendini miyokardiyal iskemiye karşı ön koruma amaçlı hazırlayabileceği, dışardan verilen antioksidan tedavinin de bu faydalı etkiyi azaltabileceği belirtilmiştir (22). Yine başka bir çalışmada, vasküler dokuların az miktarda katekolaminlere maruz bırakılması da endojen SOD ekspresyonunu artırdığını ve dışardan verilen antioksidanlarla da bu faydalı SOD sentezinin azaldığı görülmüştür (23). İskemik kalp hastalığı veya $\mathrm{KY}$ ' li hastaların klinik çalışmalarında antioksidan takviyenin başarısızığı endojen anti-oksidanların kısmi blokajı ile açıklanabilir (24).

Biz çalışmamızda, tedavi grubu ile tedavi verilip kompansasyon sağlanan hastalarda çalıştığımız parametreler arasında fark olup olmadığını araştırdık. Böylece SOR' nin ve dolayısıyla oksidatif stresin kalbin kasılma gücü ve KY' nin prognozundaki etkilerini anlamaya çalıştık. Sol ventrikül EF' si ileri derecede düşmüş olan hastalarda verilen tedavi sonrası sol ventrikül EF' nin yükseldiğini, hastaların klinik olarak düzelmesine rağmen baktığımız oksidatif stres parametrelerinin düşmediğini, hatta daha fazla arttığını tespit ettik. Bu da KY' nin tedavisi ile sağlanan reperfüzyonun sonucu, endojen antioksidanların artması sonucu olabileceğini düşündürttü.

Sonuç olarak, günümüzde oksidatif stresin $\mathrm{KY}$ ' nde arttığı ve mortalite ile yakın ilişkili olduğu düşünülmektedir. Oksidatif stres kalp kası fonksiyon bozukluğuna yol açarak, kardiyak fonksiyonlarda bozulmayı artırabilir. Çalışmamız ise, oksidatif stresin konjestif KY' nin başlangıcında yüksek olduğunu ve tedavi ile kompansasyon sağlananlarda da bu yüksek seviyelerinin devam ettiğini göstermiştir. Bilgilerimize göre literatürde akut DKKY tedavisinin bu parametreleri ne düzeyde etkilediğini gösteren çalışmalar sınırlı ve sonuçları tartışmalı olduğundan, bu konu ile ilgili daha fazla çalışma yapılmasına intiyaç olduğunu düşünüyoruz.

\section{Kaynaklar}

1. Cleland JG, Khand A, Clark A. The heart failure epidemic: Exactly how big is it? Eur Heart J 2001; 22: 623-6.

2. Packer $M$, Carver JR, Rodeheffer RJ, Ivanhoe RJ, DiBianco R, Zeldis SM. Effect of oral milrinone on mortality in severe chronic heart failure. The PROMISE Study Research Group. N Engl J Med 1991; 325: 1468-75.

3. Martin A, Foxall T, Blumberg JB, Meydani M. Alphatocopherol inhibits LDL-induced adhesion of monocytes to human aortic endothelial cells in vitro. Arterioscler Thromb Vasc Biol 1997; 17: 42936.

4. Munzel T., Gori T., Keaney J.F., Maack C., and Daiber A.: Pathophysiological role of oxidative stress in systolic and diastolic heart failure and its therapeutic implications. Eur Heart J 2015; 
36: pp. 2555-2564

5. Nakamura $\mathrm{H}$, Nakamura $\mathrm{K}$, Yodoi J: Redox regulation of cellular activation. Annu Rev Immunol 1997;15: 351-69.

6. Ceconi $\mathrm{C}$, Curello S, Cargnoni A, Ferrari R, Albertini A, Visioli O: The role of glutathione status in the protection against ischaemic and reperfusion damage: effects of $\mathrm{N}$-acetyl cysteine. J Mol Cell Cardiol 1988;20: 5-13.

7. Singh $\mathrm{A}$, Lee $\mathrm{KJ}$, Lee $\mathrm{CY}$, Goldfarb RD, Tsan MF: Relation between myocardial glutathione content and extent of ischemiareperfusion injury. Circulation 1989;80:1795-804.

8. Chen Z, Siu B, Ho YS, Vincent R, Chua CC, Hamdy RC, Chua $\mathrm{BH}$ : Overexpression of MnSOD protects against myocardial ischemia/reperfusion injury in transgenic mice. J Mol Cell Cardiol 1998;30:2281-9.

9. Woo YJ, Zhang JC, Vijayasarathy C, Zwacka RM, Englehardt JF, Gardner TJ, Sweeney HL: Recombinant adenovirus-mediated cardiac gene transfer of superoxide dismutase and catalase attenuates postischemic contractile dysfunction. Circulation 1998;98:255-60.

10. Cabigas EB, Somasuntharam I, Brown ME, Che PL, Pendergrass $\mathrm{KD}$, Chiang B, Taylor WR, Davis ME: Overexpression of catalase in myeloid cells confers acute protection following myocardial infarction. Int J Mol Sci 2014;15:9036-50.

11. Erel O. A novel automated method to measure total antioxidant response against potent free radical reactions. Clin Biochem 2004; 37: 112-9

12. Schiller NB, Shah PM, Crawford M, DeMaria A, Devereux R, Feigenbaum $\mathrm{H}$, et al. Recommendations for quantitation of the left ventricle by two-dimensional echocardiography. American Society of Echocardiography Committee on Standards, Subcommittee on Quantitation of Two-Dimensional Echocardiograms. J Am Soc Echocardiogr. 1989; 2: 358-67.

13. Schiller NB, Acquatella H, Ports TA, Drew D, Goerke J, Ringertz $\mathrm{H}$, et al. Left ventricular volume from paired biplane two-dimensional echocardiography. Circulation. 1979; 60: 547-55.

14. LeLeiko RM, Vaccari CS, Sola S, Merchant N, Nagamia SH, Thoenes $\mathrm{M}$, et al. Usefulness of elevations in serum choline and free F2)-isoprostane to predict 30-day cardiovascular outcomes in patients with acute coronary syndrome. Am J Cardiol. 2009;104: 638-43.

15. Polidori MC, Pratico D, Savino K, Rokach J, Stahl W, Mecocci P. Increased F2 isoprostane plasma levels in patients with congestive heart failure are correlated with antioxidant status and disease severity. J Card Fail. 2004;10: 334-8.

16. Hokamaki J, Kawano H, Yoshimura M, Soejima H, Miyamoto S, Kajiwara I, et al. Urinary biopyrrins levels are elevated in relation to severity of heart failure. J Am Coll Cardiol. 2004;43: 1880-5.

17. Dhalla AK, Singal PK. Antioxidant changes in hypertrophied and failing guinea pig hearts. Am J Phys. 1994;266:1280-5.

18. Hill MF, Singal PK. Right and left myocardial antioxidant responses during heart failure subsequent to myocardial infarction. Circulation. 1997;96: 2414-20.

19. Shiomi T, Tsutsui $H$, Matsusaka $H$, Murakami $K$, Hayashidani $S$, Ikeuchi M, et al. Overexpression of glutathione peroxidase prevents left ventricular remodeling and failure after myocardial infarction in mice. Circulation. 2004;109: 544-9.

20. Anker SD, Doehner W, Rauchhaus M, Sharma R, Francis D, Knosalla $C$, et al. Uric acid and survival in chronic heart failure: validation and application in metabolic, functional, and hemodynamic staging. Circulation. 2003;107: 1991-7.

21. Kunsch $C$, Medford RM. Oxidative stress as a regulator of gene expression in the vasculature. Circ Res. 1999;85: 753-66.

22. Baines $\mathrm{CP}$, Goto M, Downey JM. Oxygen radicals released during ischemic preconditioning contribute to cardioprotection in the rabbit myocardium. J Mol Cell Cardiol. 1997;29: 207-16.

23. Mehta JL, Li D. Epinephrine upregulates superoxide dismutase in human coronary artery endothelial cells. Free Radic Biol Med. 2001;30: 148-53.

24. Muzakova V, Kandar R, Vojtisek P, Skalicky J, Vankova R, Cegan $A$, et al. Antioxidant vitamin levels and glutathione peroxidase activity during ischemia/reperfusion in myocardial infarction. Physiol Res. 2001;50: 389-96. 